\title{
MUTATION BREEDING STRATEGIES FOR GLUCOSINOLATE CONTENTS IN Brassica juncea (L.) COSS. \& CZERN. Cv. Varuna
}

\section{K. N. Sathawane}

Department Of Botany, S.N. Mor Arts, Commerce And Smt. G.D. Saraf Science College, Tumsar-441912.

Corresponding Author Email Id : komal_1965@rediffmail.com

\section{ABSTRACT:}

Low glucosinolate mustard is one of the major goals for quality oil and meal. To achieve this goal seeds of Brassica juncea (L.) COSS \& CZERN CV. Varuna were treated with different concentrations of ethyl methane sulfonate and sodium azide. The mutagenized seeds were sown in the field to raise $M_{1}$ generation. Seeds of $M_{1}$ generation were harvested plant - wise and sown in the field to raise $\mathrm{M}_{2}$ generation. $\mathrm{M}_{2}$ seeds were harvested plant - wise and analyzed by Tes-tape for glucosinolate content. $\mathrm{M}_{2}$ seeds with Westar level $(<20 \mu \mathrm{mole} / \mathrm{gm}$ of deoiled meal) glucosinolate were selected. Glucosinolate levels were divided into three different categories depending upon the glucosinolate content. The Westar seeds contain $<20 \mu$ mole of glucosinolate while control seeds of Varuna has about $>155 \mu$ mole of glucosinolate. Hence, Westar level selected varuna seeds were sown in the field to raise $\mathrm{M}_{3}$ generation. All plants were selfed and on maturity, harvested plant - wise. Upon screening for Westar level glucosinolate, the $M_{3}$ seeds showed variable levels of glucosinolate. $M_{3}$ seeds were observed to segregate in medium and high level of glucosinolate. The data obtained indicate positive possibilities of induced low glucosinolate mutation, however, the following generation need careful handling, selfing, crossing, screening and large population size.

Keywords: - Brassia juncea, Glucosinolate, Mutation breeding strategies, EMS, Sodium azide.

\section{INTRODUCTION: -}

Brassica juncea $\mathrm{Cv}$. Varuna is a major oil yielding crop in India. It is commonly known as Indian mustard. After extraction of oil the remaining meal of mustard could become an important animal feed. The mustard meal has about 35 to $40 \%$ of crude protein content. This highly proteinaceous fraction increases the dietary value of the meal for animals. However, due to the presence of Glucosinolate the Indian mustard meal has limited usage. Indian mustard B. juncea Cv. Varuna has about $>155 \mu$ mole of Glucosinolate/gm of deoiled meal. Hence, investigations on induced mutation for glucosinolate 
content in $B$. juncea $\mathrm{Cv}$. Varuna were undertaken. Mutagens exposed populations have been screened for three generations. Results obtained have indicated certain problems which are discussed in this presentation.

\section{MATERIAL AND METHODS:}

Genetically pure and physiologically uniform $B$. juncea Cv. Varuna seeds were exposed to different doses of ethyl methane sulfonate (EMS) and sodium azide (SA). All concentration of EMS and SA were prepared on $\mathrm{V} / \mathrm{V}$ and $\mathrm{V} / \mathrm{W}$ basis, respectively. The mutagen treated seeds were utilized to raise M1 generation. They were harvested plant-wise and $\mathrm{M}_{2}$ population raised. $\mathrm{M}_{2}$ seeds were screened for glucosinolate content by Tes-tape method /1,3,5/. Seeds of Westar (B. napus) were used as low glucosinolate standard whereas non treated seeds of Varuna used as control. Upon selection, the $\mathrm{M}_{2}$ low glucosinolate seeds were sown to raise the $\mathrm{M}_{3}$ generation. $\mathrm{M}_{3}$ seeds were screened for low glucosinolate. The levels of glucosinolate were categorized into 3 different types $(-),( \pm)$ and $(+)$ on the basis of presence or absence of glucosinolate.

\section{RESULTS AND DISCUSSION:}

In 1960's, Bronoski, identified a plant of B. napus Cv. Polish with low glucosinolate (about 10 to $12 \mu \mathrm{mole} / \mathrm{gm}$ of deoiled meal). Since-then the efforts to produce low glucosinolate Brassica species have caught speed. Westar (B. napus) was the first '00' produced in Canada.. Low glucosinolate lines of $B$. napus cannot grow in Indian agro -climate due to its long day dependency. Hence, efforts were made in our laboratory to induce mutation for low glucosinolate in $B$. juncea $\mathrm{Cv}$. Varuna.

In the present investigation, the data obtained on glucosinolate level of $\mathrm{M}_{2}$ and $\mathrm{M}_{3}$ generations are recorded in table 1 and 2 , respectively. The data obtained in $\mathrm{M}_{2}$ show that Westar level of glucosinolate was recorded in $12 \mathrm{hPsw}$ $+3 \mathrm{~h}$ SA $0.03 \% ; 12 \mathrm{~h} \mathrm{SA} 0.008 \%$ and $18 \mathrm{~h}$ SA $0.008 \%$ treatments. While $( \pm)$ level of glucosinolate was observed in $12 \mathrm{~h}$ Psw $+3 \mathrm{~h}$ SA $0.03 \%$. Remaining treatment had plants with $( \pm)$ level of glucosinolate. However, 12 h SA $0.008 \%$ 
did not have any low glucosinolate plants. Plants with ( \pm ) level of glucosinolate were more (5) in $18 \mathrm{~h}$ EMS $0.01 \%$ whereas in $12 \mathrm{~h}$ Psw $+3 \mathrm{~h} 0.03 \%$ and $12 \mathrm{~h}$ EMS $0.01 \%$, the $(+)$ level of glucosinolate was not observed. 12h Psw $+3 \mathrm{~h}$ SA $0.03 \%, 12 \mathrm{~h}$ SA $0.008 \%$ and $18 \mathrm{~h}$ SA $0.008 \%$ treatments had two plants with $(+)$ level. The M3 data for glucosinolate content are surprisingly different than $\mathrm{M}_{2}$ (Table 2), the Westar level of glucosinolate plant was not recorded in M3 however, $12 \mathrm{~h}$ SA $0.008 \%, \quad 18 \mathrm{~h}$ SA $0.008 \%$ and $12 \mathrm{~h}$ Psw $+3 \mathrm{~h}$ SA $0.03 \%$ showed 4,2 and 1 plants with $( \pm)$ level of glucosinolate, respectively. The $(+)$ level of glucosinolate was apparent in all treatments in $\mathrm{M}_{3}$ except $12 \mathrm{~h} \mathrm{Psw}+3 \mathrm{~h}$ EMS 0.03\%.

These results clearly indicate that the breeding for glucosinolate is intricate. The glucosinolate level in Brassica is controlled by more than one locus with multiple alleles having additive effects/4. The (-) level glucosinolate plants were identified in $\mathrm{M}_{2}$ generation but it segregated in the next generation. Such precious alterations can always get lost by improper handling of population. Therefore to breed low glucosinolate $B$. juncea the breeder must have well planned strategies. Some of the suggestions which have emerged out of our work are:

1. It is necessary to grow large population of $M_{3}, M_{4}$ and $M_{5}$ generations. Undertake screening of low glucosinolate character in $\mathrm{M}_{5}$ generation and grow isolated Westar level lows in $\mathrm{M}_{6}$ and self, screen and grow $\mathrm{M}_{7}, \mathrm{M}_{8}$, and M9 generations and evolve low glucosinolate lines.

2. By making crosses between (-) level glucosinolate plants or with either of $( \pm)$ and $(+)$ plants and grow $F_{1}, F_{2}$ and screen $F_{2}$ for low glucosinolate and then advance the material with desirable character.

3. Another approach is, microspore culture, the microspores of $(-),( \pm)$ and $(+)$ levels glucosinolate plants could be cultured and diplodized. Selection for low glucosinolate could be practiced in diploids which should be homozygous for low glucosinolate character. 
4. Effective selfing of each inflorescence, plant-wise harvesting, correct way of analyzing the seeds and huge population size could increase the chance of getting low glucosinolate plants.

\section{ACKNOWLEDGEMENT:}

This investigation was made possible by the grant from B.R.N.S. .

\section{REFERENCES:}

Comer, J.P. 1956, Semi-quantitative specific test paper for glucose in urine. Anal. Che. 28: 1748-1750.

Klassen, A.J., R.K. Downey and J.J. Capcara. 1987 - Westar summer rape. Can. J. Plant Sci. 67: 491-493.

Lein, K.A. 1970 - Methods for quantitative determination of seed glucosinolate of Brassica species and their application in plant breeding of rape low in Glucosinolate content. Z. Pflanzenzuecht 63: 137 - 154.

Love, H.K., G. Rakow, J.P. Raney and R.K. Downey. 1990 - Genetic control of 2propeny 1 and 3-buteny1 glucosinolate in mustard. Can. J. Plant Sci. 70: 425-429.

McGregor, D.I. and R.K. Downey. 1975 - A rapid and simple assay for identifying low glucosinolate rape. Can. J. Plant Sci. 55: 191-196. 
TABLE: - 1 FREQUENCY OF LOW GLUCOSINOLATE PLANTS IN $M_{2}$

\begin{tabular}{|c|c|c|c|c|c|c|c|}
\hline \multirow[t]{2}{*}{ Tre } & \multirow[t]{2}{*}{$\begin{array}{c}\text { Total No. of } \\
\text { Plants } \\
\text { studied }\end{array}$} & \multicolumn{3}{|c|}{$\begin{array}{c}\text { Number of } \\
\text { Plants with } \\
\text { different } \\
\text { glucosinolate } \\
\text { levels }\end{array}$} & \multicolumn{3}{|c|}{$\begin{array}{l}\text { Frequency per } \\
100 \mathrm{M}_{2} \text { plants }\end{array}$} \\
\hline & & - & + & + & - & $\begin{array}{l}+ \\
-\end{array}$ & + \\
\hline $\begin{array}{l}\text { Control (B. juncea } \\
\mathrm{Cv} \text {. Varuna }\end{array}$ & 17 & - & $\overline{-}$ & - & - & - & - \\
\hline Westar (B. napus) & 17 & 17 & - & - & 100 & - & - \\
\hline $\begin{array}{l}12 \mathrm{~h} \text { Psw + 3h EMS } \\
0.03 \%\end{array}$ & 411 & - & 1 & - & - & 0.24 & - \\
\hline $\begin{array}{l}12 \mathrm{~h} \mathrm{Psw}+3 \mathrm{~h} \mathrm{SA} \\
0.03 \%\end{array}$ & 227 & 1 & 4 & 2 & 0.44 & 1.76 & 0.88 \\
\hline $12 \mathrm{~h}$ EMS $0.01 \%$ & 290 & - & 1 & - & _ & 0.34 & - \\
\hline $12 \mathrm{~h} \mathrm{SA} 0.008 \%$ & 244 & 1 & - & 2 & 0.44 & - & 0.89 \\
\hline 18h EMS 0.01\% & 262 & - & 1 & 5 & - & 0.38 & 1.90 \\
\hline $18 \mathrm{~h}$ SA $0.008 \%$ & 245 & 1 & - & 2 & 0.40 & - & 0.81 \\
\hline
\end{tabular}

TABLE:- 2 FREQUENCY OF LOW GLUCOSINOLATE PLANTS IN $M_{3}$

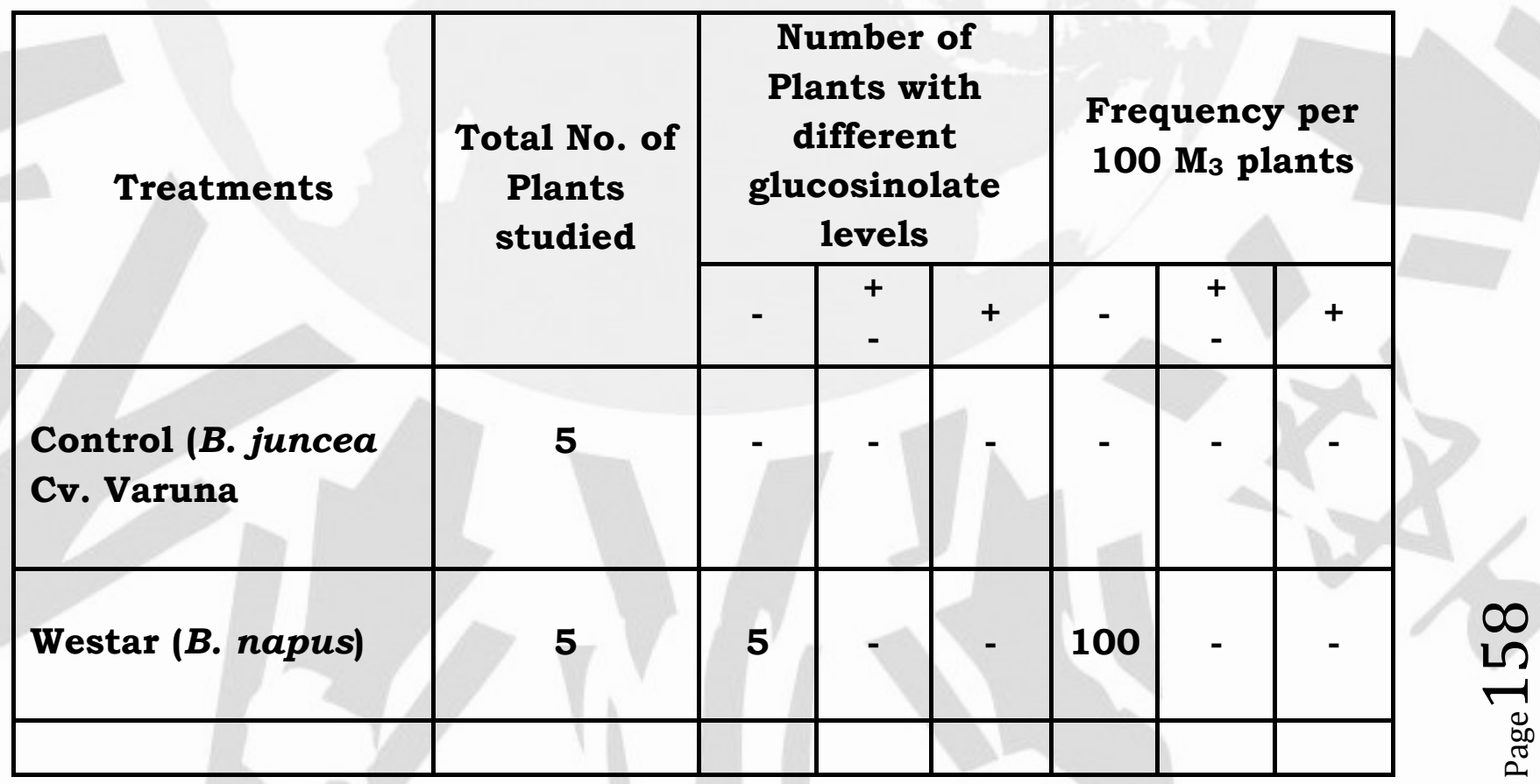


International Journal of Researches in Biosciences, Agriculture \& Technology

September 2013

Issue-1, Volume-1
ISSN No. (Online):

2347-517X

\begin{tabular}{|l|c|c|c|c|c|c|c|}
\hline $\begin{array}{l}12 \mathrm{~h} \text { Psw + 3h EMS } \\
0.03 \%\end{array}$ & - & - & - & - & - & - & - \\
\hline $\begin{array}{l}12 \mathrm{~h} \text { Psw + 3h SA } \\
0.03 \%\end{array}$ & 96 & - & 1 & 6 & - & 1.04 & 6.2 \\
\hline $12 \mathrm{~h}$ EMS 0.01\% & 49 & - & - & 4 & - & - & 8.16 \\
\hline $12 \mathrm{~h}$ SA 0.008\% & 63 & - & 4 & 19 & - & 6.3 & 30.1 \\
\hline $18 \mathrm{~h} \mathrm{EMS} \mathrm{0.01 \%}$ & 49 & - & - & 4 & - & - & 8.16 \\
\hline $18 \mathrm{~h} \mathrm{SA} \mathrm{0.008 \%}$ & 19 & - & 2 & 11 & - & 10.5 & 57.8 \\
\hline
\end{tabular}

